Canadian Studies in Population, Vol. 16 (2), pp 217-236

\title{
STABLE POPULATION SIZE: MONTSERRAT
}

\author{
G. Edward Ebanks \\ University of Western Ontario, London, Ontario, Canada
}

Résumé - Montserrat, une petite île des Caraỉbes a maintenu une dimension de population relativement stable pendant les dernières quatre-vingt-quinze années. La dimension de la population entre 1891 et 1986 (à l'exception de celle de 1946) a été aux environs de 12,000 . Une telle stabilité est rare, particulièrement dans le cas d'une société en voie de développement. Cette stabilité n'est quand même pas due à une perte de la solde migratoire. Indirectement de plus, l'émigration a supprimé la fécondité, a vieilli la population et a augmenté le taux brut de mortalité. Relativement élevée, la qualité de vie de Montserrat est, en partie, une conséquence de cette stabilité relative dans la dimension de population au cours des dernières cent années.

Abstract - Montserrat, a small Caribbean island, has maintained a relatively stable population size for the past 95 years. The size of the population between 1891 and 1986 (except for 1946) has been around 12,000. Such stability is rare, especially for a developing society. This stability is in no small way due to net-migration loss. Indirectly also, emigration has suppressed fertility, aged the population and increased the crude death rate. Montserrat's relatively high quality of life is in part a consequence of this relative stability in the size of the population over the last one hundred years.

Key Words - Montserrat, stable population, net-migration loss 


\section{G. Edward Ebanks}

\section{Introduction}

This paper examines the population situation in Montserrat, a small Caribbean island, for the period 1871 to 1986 with major attention being given to the period since 1960 . During this period, Montserrat has been consistently placed among the less developed areas. Consequently, one would expect its population size to be increasing. In fact it is usual for countries comparable to Montserrat in economic development to have tripled their population sizes over these 115 years. But this has not been the case for Montserrat. In spite of fluctuations in the size of the population, there has been a very strong tendency to vary within a narrow range, achieving a great measure of stability. Why is this the case? What have been the consequences? Answers to these questions are sought in this paper.

One could speculate that Montserrat's relative stability is an outcome of high crude death rates balancing high crude birth rates, a situation associated with the first phase of the demographic transition. However, this is not the case. Based on its vital rates and rate of natural increase, it is possible to conclude that Montserrat has made progress through the transition phases and is now entering the slow growth period characteristic of the third phase where the crude birth rate and the crude death rate are relatively low and natural increase is declining.

\section{Data}

The data for this paper are derived from publications of the Statistical Office of the Government of Montserrat dealing with vital statistics and census data. Three censuses are used (1960, 1970, and 1980). Estimates and projections are also utilized. The censuses are part of the English-speaking Caribbean series and have been evaluated as relatively complete and reliable. The vital statistics are considererd to be of high quality. The estimates and projections have been made by experts using good base data and defensible assumptions. However, like most demographic data one must be cautious in using them. One should focus upon trends over time and not over-emphasize small differences. Data on migration are nearly always of doubtful quality. Those for Montserrat are perhaps no worse than those of the other English speaking Caribbean countries. Arrivals and departures are recorded and eventually reconciled. However, departures or arrivals on private carriers may go unrecorded. 


\section{Montserrat: A Brief Description}

Montserrat - a micro, English speaking, northeastern Caribbean island has a land area of 102.7 square kilometres (39.5 square miles) with a current population of approximately 12,000 . It is 17.6 kilometres (11 miles) in length and has a maximum width of 11.2 kilometres ( 7 miles). It is one of the Leeward Islands of the Lesser Antilles and is about equal distance from Antigua and Guadeloupe (43 kilometres). On the west side of the island the vegetation is green and lush, while on the east side it is mainly scrub bush and grass. The island is volcanic in nature with volcanic peaks rising to a height of about 900 metres (3,000 feet) at Chance's Peak. The land slopes steeply up from the sea with only small amounts of level ground. Rivers flow rapidly into the sea. Montserrat's beaches are covered with black sand in comparison to the white coral sands of its neighbour, Antigua. The climate is pleasant since the humidity is relatively low. Its rivers and relative abundance of rainfall provide it with an ample supply of water for its population.

Originally discovered by Columbus in 1493 and named by him because of its resemblance to Montserrat in Spain, it was not settled until around 1632-33. The first settlers are said to have been Irish Catholics from nearby St. Kitts. Except for two brief periods of capture by the French, Montserrat has been British for its recorded history. Today, it is one of the six small remaining British colonies in the Caribbean which include: Cayman Islands, Turks and Caicos Islands, British Virgin Islands, Anguilla, Montserrat and Bermuda. However, it does enjoy a very large measure of self-govemment. Independence is Montserrat's for the asking since the British are anxious to transfer power to its Caribben colonies. It is a member of Caricom (Caribben Common Market), and of the Organization of Eastern Caribbean States (OECS).

The population of Montserrat enjoys a relatively high quality of life. Health conditions are fairly good; the crime rate is low and the country has been politically stable. Although the cost of living is high for Montserratians, it may be deemed reasonable for those with a foreign income, families receiving remittances from relatives who have emigrated, and retirees with a foreign pension or other income from abroad. Economically, Montserrat has done quite well in recent years. The gross domestic product (GDP) per capita (at market prices) which was about EC $\$ 2,200$ (US $\$ 800$ ) in 1975 was estimated in 1985 to be nearly EC $\$ 8,500$ (US $\$ 3,100$ ), an almost four-fold increase, which put Montserrat at a level above that of most OECS countries, as well as Jamaica, Guyana and Belize. However, the real increase at constant prices, i.e., deducting price increases or inflation, has been only 40 per cent between 1975 and 1985, but still a substantial increase. The economy of the island is now largely service 


\section{G. Edward Ebanks}

oriented. Indeed, the finance, insurance, real estate and business services sector contributes nearly 25 per cent of the GDP; the community, social and personnel services sector 22 per cent; and the trade, hotels, bars and restaurants 20 per cent. The main source of foreign earnings is tourism with some contribution to the foreign exchange earnings from agricultural exports. Other important sources of foreign earnings are remittances from citizens living abroad, foreign income of retirees, foreign investment and external aid. The foreign debt is small, unemployment is relatively low and labour productivity relatively high. A stable population size mainly due to emigration is an important factor in determining the economic situation.

\section{The Population of Montserrat}

\section{Population Size}

Table 1 presents data on the size of the population. These statistics are drawn from censuses taken from 1871 to 1980 , and the annual population estimates made by the Statistics Office for the non-census years between 1970 and 1986. There has been no adjustment of the 1970-79 estimates made prior to the 1980 census, after the results of this census were known. As the 1979 estimate was slightly lower than was suggested by the 1980 census result, the lack of adjustment of the underestimated figure for 1979 translated into an annual increase between 1979 and 1980 of 385, which is undoubtedly an inflated figure. The estimates are obtained by taking into consideration the natural increase and net migration. It is assumed that net-migration figures are less accurate than the natural increase ones. Adjustments based solely on the census figures of 1970 and 1980 would show hardly any change betwen 1971 and 1979 since the difference between the 1970 census figure and the 1980 is only 108 or an average of about 11 per year. The unadjusted figures capture the yearly changes in vital events and net migration. The use of a moving average technique using a three year rolling average would smooth out the 1971 to 1979 figures somewhat, but this seems hardly justifiable or even defensible. In so doing, we would be making a great deal over small differences at the same time casting aspersions on the vital registration and migration data systems. Year to year fluctuations are to be expected when dealing with small numbers (population size, births, deaths, departures, and arrivals).

The population of Montserrat grew between 1871 and 1881 by 1390, an average of about 139 per year (Table 1, Figure 1). Between 1881 and 1891 the 


\section{TABLE 1.POPULATION SIZE AND GROWTH, 1871-1986}

\begin{tabular}{|c|c|c|c|c|c|}
\hline \multirow[t]{2}{*}{ Year } & \multicolumn{3}{|c|}{ Population } & \multicolumn{2}{|c|}{ Population Growth } \\
\hline & Male & Female & Total & $\begin{array}{c}\text { Average } \\
\text { Annual Increase }\end{array}$ & $\begin{array}{l}\text { Average Percent } \\
\text { Growth per Annum }\end{array}$ \\
\hline 1871 & 3978 & 4715 & 8693 & -- & -- \\
\hline 1881 & 4639 & 5444 & 10083 & 139 & 1.60 \\
\hline 1891 & 5331 & 6431 & 11762 & 168 & 1.67 \\
\hline 1901 & 5580 & 6635 & 12215 & 45 & 0.39 \\
\hline 1911 & 5245 & 6951 & 12196 & -2 & -0.02 \\
\hline 1921 & 5094 & 7026 & 12120 & -8 & -0.06 \\
\hline 1946 & 6362 & 7971 & 14333 & 89 & 0.73 \\
\hline 1960 & 5407 & 6760 & 12167 & -155 & -1.27 \\
\hline 1970 & 5395 & 6103 & 11498 & -67 & -0.58 \\
\hline 1971 & 4851 & 6700 & 11551 & 53 & 0.46 \\
\hline 1972 & 4948 & 6745 & 11693 & 142 & 1.2 \\
\hline 1973 & 5155 & 6410 & 11565 & -128 & -1.1 \\
\hline 1974 & 5234 & 6552 & 11786 & 221 & 1.9 \\
\hline .1975 & 5459 & 6285 & 11744 & -42 & -0.4 \\
\hline 1976 & 5366 & 6281 & 11647 & -97 & -0.8 \\
\hline 1977 & 5392 & 6102 & 11494 & -153 & -1.3 \\
\hline 1978 & 5250 & 6002 & 11252 & -242 & -2.1 \\
\hline 1979 & 5254 & 5967 & 11221 & -31 & -0.3 \\
\hline 1980 & 5582 & 6024 & 11606 & 385 & 3.4 \\
\hline 1981 & 5608 & 6012 & 11620 & 14 & 0.1 \\
\hline 1982 & 5645 & 6030 & 11675 & 64 & 0.5 \\
\hline 1983 & 5663 & 6070 & 11733 & 58 & 0.5 \\
\hline 1984 & 5700 & 6093 & 11793 & 60 & 0.5 \\
\hline 1985 & 5748 & 6104 & 11852 & 59 & 0.5 \\
\hline 1986 & NA & $\mathrm{NA}$ & 11888 & 36 & 0.3 \\
\hline $1970-80$ & & & & 11 & 0.09 \\
\hline
\end{tabular}

Sources: Government of Montserrat, Statisties office 9th Statistical Digest 1984, Report on Vital Statistics 1985, and 1980 Census vol. 3.

increase was 1679, an annual average increase of 168 and between 1891 and 1901 the average annual increase was 45 . The size of the population at the beginning of the 20th century (1901) was 12,215 . This population size has been exceeded in the 20th century only by the census population of 1946 , when the total population was 14,333 . Over the period $1871-1986$, no other figure has approached that of 1946. The Great Depression and the Second World War disrupted international migration and gave rise to an average yearly increase of 189 between 1921 and 1946.

The period 1901-1921 saw a slight decline in the size of the population of Montserrat. It is hypothesized that this was due to low natural increase and significant net-migration loss. Between 1946 and 1960 the average yearly decline in the total population was 155 . It is suspected that during this period 


\section{G. Edward Ebanks}

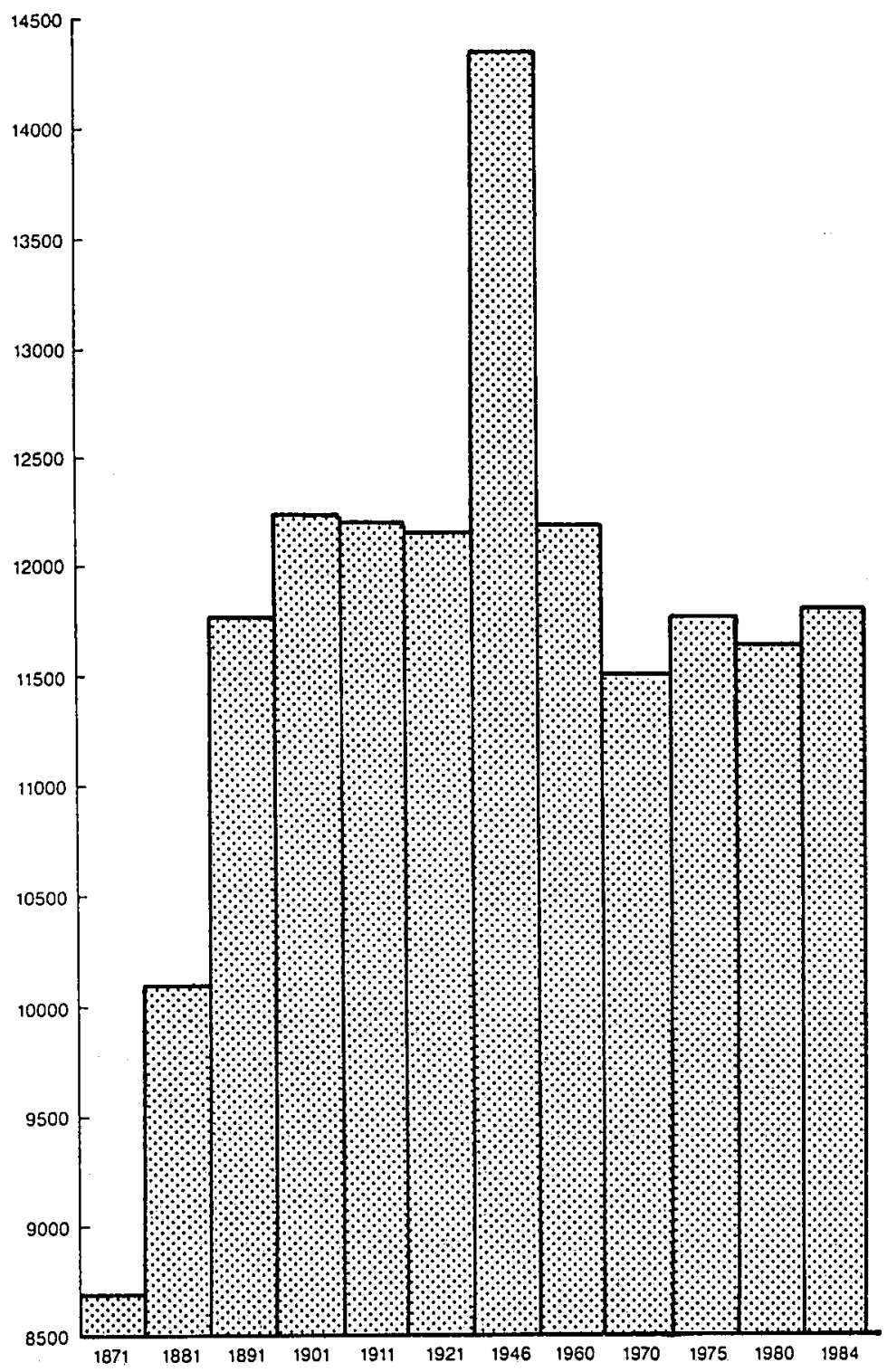

FIGURE 1.POPULATION OF MONTESERRAT, 1871-1984 
the rate of natural increase was wiped out by net-migration loss. Between 1970 and 1980 the size of the population increased by an average of 11 persons per year. Net migration is low, and natural increase is declining during the most recent period.

In the early 1980 s, the population was again approaching 12,000 . Indeed, since 1960 , it is safe to generalize by saying that the population size has stabilized at close to 12,000 . Years of negative increases seem to be balanced out by years of positive ones. With one exception (1946), the population of Montserrat has been close to 12,000 between 1891 and 1986, a period of 95 years.

The changing size of the population is therefore not the major factor in the economic planning for the island. It will be seen, however, that the composition of the population is an important consideration since it has not had the same tendency toward stability as has been seen with respect to the total population. In fact, the factors determining the size of the population have changed over time, but their individual effects compensated for each other, hence a fairly stable population size is observed. Unfortunately, a lack of data on the determinants of population size prevents analysis over the entire period.

\section{Population Growth}

The average annual increases in the population are shown in Table 1. Also shown are the average annual growth rates for the intercensal periods from 1871-81 to 1970-80, and the annual increases from 1970 to 1986 . For the 115 year period shown in Table 1, the average annual rate of growth is a mere 0.3 per cent. This increase all occurred in the 19 th century, since the difference between the population at the beginning of the 20th century and that in 1986 is negative. While very low to negative growth rates are being experienced in Montserrat, the population of the world and that of the Caribbean neighbours have been exploding during the 20th century. This is a very fascinating feature of the Montserrat situation. This lack of growth in the population cannot be attributed to such conventional factors as high birth rates combined with high death rates remaining in force. The size of the island and its resource base do not provide the answers since most countries in the Caribbean and worldwide in similar situations have grown.

In fact, like its neighbours, Montserrat has been experiencing the demographic transition, that is the shift from high to low levels of both mortality and fertility. During the demographic transition process, as mortality decline starts first while fertility remains high before declining later, population growth 


\section{G. Edward Ebanks}

is high as a result of high natural increase. The high rate of natural increase associated with phase two of the demographic transition seems to have been confined to the period 1921 to 1946 , when it is likely migration was greatly curtailed because of the Great Depression and the ensuing World War II. It can be conjectured that, except for the period 1921 to 1946, migration has played a decisive role in determining the size and rate of growth of tiny Montserrat.

All growth rates, except 1979 to $1980(3.4 \%)$, are relatively small for a country at Montserrat's level of socio-economic development. As explained before, the rate for 1979-1980 is no doubt inflated due to an underestimate of the 1979 population in comparison with the 1980 census population. Indeed, when we compare the 1970 census population with that of 1980 we find that the average annual intercensal growth is only 0.09 per cent (Table 1 ).

\section{Components of Growth}

Negative and slow rates of growth of the population have been shown in the previous section. Knowledge of the labour-market situation in Montserrat leads to the speculation that outmigration is a major factor determining the rate of growth and size of the population of Montserrat. In this section we look at fertility as measured by the number of live births per 1,000 population, that is the crude birth rate (CBR); mortality as measured by the number of deaths per 1,000 population, that is the crude death rate (CDR); and net migration, that is the loss or gain due to migration expressed per 1,000 population. This is done for the most recent period $1970-85$ only, since it is impossible to obtain comparable figures for the pre-1970 period.

Crude birth rates. The crude birth rate in 1960 was estimated at 29.5 per thousand population. At this time, it is relatively low for a country such as Montserrat. However, outmigration certainly played a significant role in keeping the crude birth rates low. Emigrants are generally age-sex selective, (i.e., predominantly young adults and generally male or female dominant) and in the prime childbearing ages. Sex-selective migration reduces fertility, since the stayers are less likely to find suitable partners. Age-selective emigration results in decreasing the number of people in the prime childbearing ages.

Between 1960 and 1970 the crude birth rate fell 3 points to 26.4 (Table 2 and Figure 2). It fluctuated between 23 and 27 until 1975 when it fell below 20 and remained there until 1979, in which year it jumped to 21 . The period 1979 to 1985 saw the crude birth rate hovering above 19 and below 23, and in 1986 it stands at 17 . Overall, the period 1970-78 was one of modest though fluctuat- 
Stable Population Size: Montserrat

TABLE 2. COMPONENTS OF POPULATION GROWTH, 1970-86

$\begin{array}{cccccr}\text { Year } & \begin{array}{c}\text { Crude } \\ \text { Birth Rate } \\ (1)\end{array} & \begin{array}{c}\text { Crude } \\ \text { Death Rate } \\ (1)\end{array} & \begin{array}{c}\text { Rate of } \\ \text { Natural } \\ \text { Increase }\end{array} & \begin{array}{c}\text { Net } \\ \text { Migration } \\ \text { kate (1) }\end{array} & \begin{array}{r}\text { Annual } \\ \text { Percent } \\ \text { Growth (8) }\end{array} \\ 1970 & 26.4 & 10.6 & 1.58 & -4.5 & 1.13 \\ 1971 & 23.2 & 10.6 & 1.26 & -2.9 & 0.97 \\ 1972 & 27.2 & 12.3 & 1.49 & -2.7 & 1.22 \\ 1973 & 25.5 & 9.2 & 1.63 & -27.3 & -1.10 \\ 1974 & 25.8 & 11.1 & 1.47 & +4.1 & 1.88 \\ 1975 & 18.1 & 10.9 & 0.72 & -10.8 & -0.36 \\ 1976 & 17.7 & 11.0 & 0.67 & -15.0 & -0.83 \\ 1977 & 17.8 & 12.0 & 0.58 & -19.1 & -1.33 \\ 1978 & 17.1 & 13.1 & 0.40 & -25.5 & -2.15 \\ 1979 & 21.2 & 10.3 & 1.09 & -13.6 & -0.27 \\ 1980 & 19.3 & 8.9 & 1.04 & +22.7 & 3.31 \\ 1981 & 19.9 & 10.1 & 0.98 & -8.6 & 0.12 \\ 1982 & 22.3 & 9.9 & 1.24 & -7.8 & 0.46 \\ 1983 & 22.6 & 10.6 & 1.20 & -7.2 & 0.48 \\ 1984 & 20.7 & 8.8 & 1.19 & -6.8 & 0.51 \\ 1985 & 21.0 & 11.5 & 0.95 & -4.6 & 0.50 \\ 1986 & 17.2 & 9.8 & 0.74 & \text { NA } & 0.30\end{array}$

(1) Per 1000 population

Source: Government of Montserrat, Statistics Office, 9 th Statistical Digest, 1984, and loth Statistical Digest 1985, Report on Vital Statistics 1985.

ing decline and the period 1979 to 1985 one of stabilization reflecting a somewhat stable pattern of fertility. The crude birth rate in Montserrat is now relatively low. Its apparent current stability around 20 is occurring in conjunction with slowdowns in net migration loss.

Crude death rates. The crude death rate in 1960 was 11.6 per thousand. The infant mortality rate in 1960 was 114, which is an indication of the relatively low level of socioeconomic development. As with the crude birth rate, the crude death rate is affected by the age composition of the population. Also we should be aware that, as with fertility, the number of events in this small population in any one year is very small and hence delays in the timing of recording and small omissions can substantially affect the rates.

The crude death rate in 1970 was 10.6 , showing a one point drop in the 10 years since 1960 and by 1980 it had fallen to 9 . In between these points in time, it fluctuated betwcen 9 and 13 (Table 2, Figure 2). There is a strong tendency 
G. Edward Ebanks

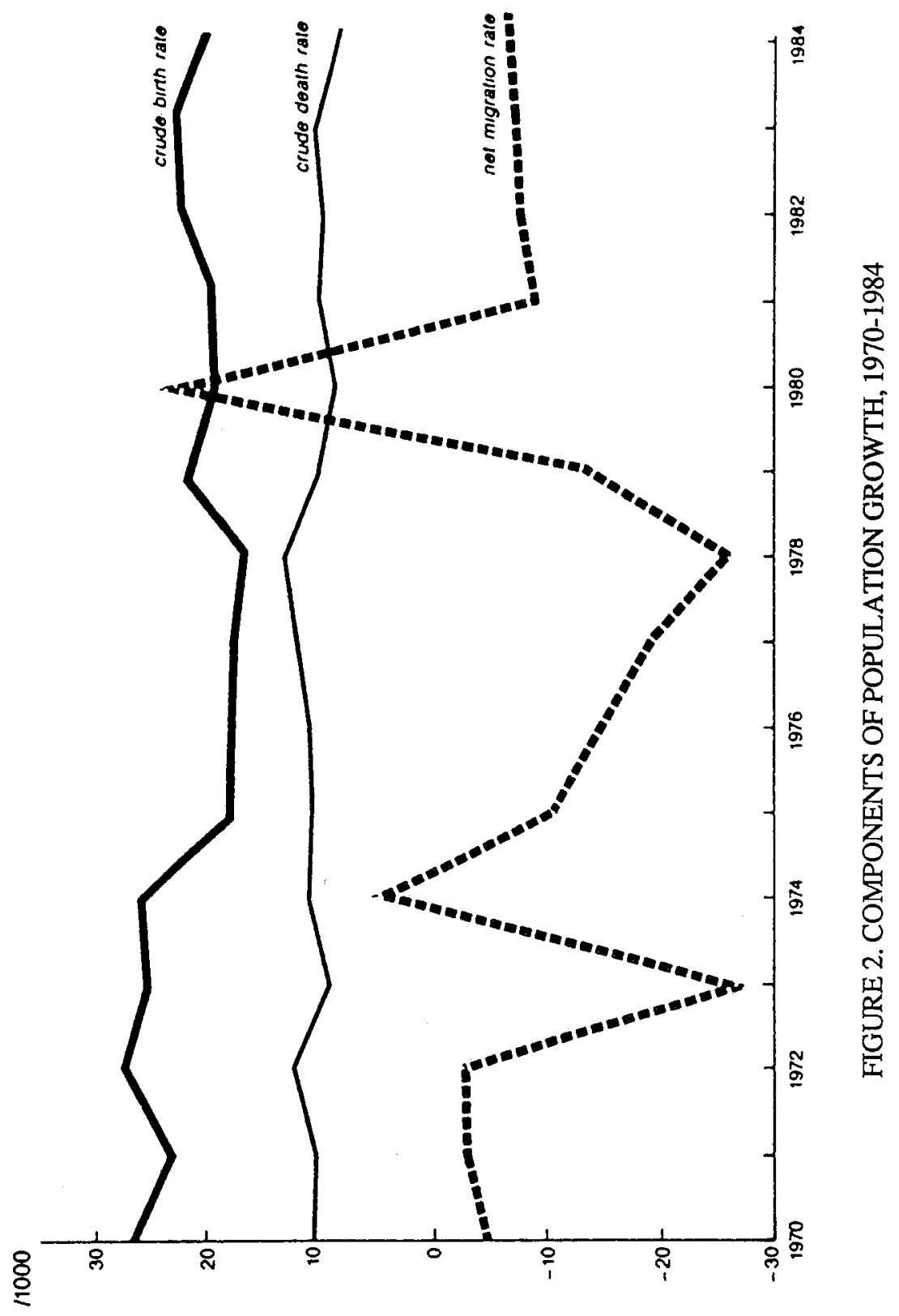


since at least 1960 for the crude death rate to remain fairly stable. Since 1980 it has fluctuated between 9 and 11.5 (1985). Figure 2 shows the small variations in the crude death rate between 1970 and 1984.

The crude death rate is relatively low in Montserrat and has been so for some time. However, at no time in recent years has the crude death rate attained the low levels of 6 to 7 recorded in other Caribbean islands. This is a result of an older age structure than in the other Caribbean countries due to continued significant levels of outmigration of young adults.

Relatively low crude birth rates and high crude death rates, in addition to net-migration losses have combined to produce the low growth rates discussed in the population growth section.

Net migration In general, one can characterize Montserrat as a country of outmigration. Net-migration losses have been estimated at about 4,500 between 1950 and 1959; 2,600 between 1960 and 1969; and 1,100 between 1970 and 1979. Since about 1950, all English speaking Caribbean islands have been experiencing significant net-migration losses. From Table 2 and Figure 2 it can be seen that since 1970, only in 1974 and 1980 have there been net-migration gains, 48 and 264, respectively. This positive net gain of 312 is outweighed by a net loss of 1,805 for the other years between 1970 and 1985 resulting in a net loss of 1,493 from the population of Montserrat. Had there been no migration loss since 1970, the population of Montserrat in 1985 would have been approximately 13,300 instead of the estimated 11,852 . This of course excludes children that would have been born to the emigrants had they remained in Montserrat.

Net-migration losses were greatest in the years 1973, and 1975-79. The period 1981-85 experienced annual net losses of between 100 and 50 people. Migration loss is currently down, but it is still substantial, considering the population base. These net-migration losses occur in spite of return migration and a small inflow of retirees from North America and Europe. Now showing up in these migration figures are students from overseas attending the offshore medical school on the island.

The age-selective emigration (i.e., young adults of both sexes) has had an impact on the crude birth and death rates and this is likely to continue. The inflow of returnees is difficult to predict. The future of the medical school is uncertain. The same is true for the immigration of retirees. The overall future impact of migration on the rate of growh and size of the population is uncertain. 


\section{G. Edward Ebanks}

Age-sex Composition

Montserrat has been experiencing declining fertility and mortality and varying levels of net-migration loss. In this section we look at the consequences of these processes as manifested in the age-sex composition for the census years 1960, 1970, and 1980 (Table 3 and Figure 3) and a recent estimate for the year 1985 .

Age composition. The population under 20 years of age has been accounting for a declining percentage of the total as a result of the declining fertility over the period 1960-80. The percentage of the population less than twenty years declined from 53.5 per cent in 1960 down to 39.5 in 1985 . The population under 15 years of age declined from 42.7 per cent in 1960 to 39.7 in $1970,31.9$ in 1980 and 28.8 in 1985.

The population 65 years and over has been increasing its percentage share of the overall population, rising from 8.1 per cent in 1960 to 10.9 in 1970 and 13.1 in 1980; then decreasing slightly to 12.8 for the 1985 estimate.

The population pyramids of Figure 3 show these changes graphically. The narrow middle of the pyramids reflect the effect of net-migration loss, a factor partly responsible for the high proportions seen for those less than 15 and over 65 years of age.

The combined effects of declining fertility and net-migration loss are seen in these age distributions. The relatively high number of births before 1960 and 1970 are reflected in the 1960 and 1970 pyramids by the high percentage of the population under 15 years of age. The high percentage over age 64 is more a consequence of the emigration of young adults. These high percentages at 65 and over are seen for the developed societies with their low fertility levels. But it is obvious that fertility was not low in Montserrat until recently. Hence net migration serves the same function as fertility in influencing the aging process of the population. Montserrat's population for 1960 has an age distribution indicative of a population with high fertility (43 per cent of the population below age 15), although the proportion of persons 65 years and over ( 8.1 per cent) was substantial for a high fertility population. This is the joint effect of high fertility and significant net-migration loss in the 1950's.

The early 1980's picture with respect to the age composition reflects low and declining fertility and still significant net-migration loss and gains in retirees. The percentage of the population younger than 15 is similar to that of such countries as South Korea, Taiwan, Argentina and Chile and just slightly 
Stable Population Size: Montserrat

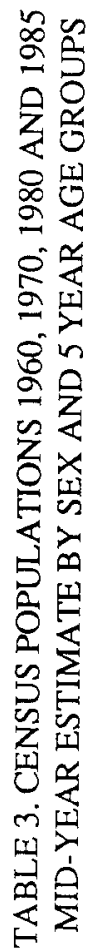

\begin{tabular}{|c|c|c|}
\hline \multirow{3}{*}{ 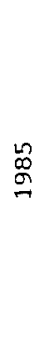 } & $\underset{\substack{\pi \\
0}}{\pi}$ & vo \\
\hline & $\underset{\substack{\pi \\
\tilde{W}}}{\stackrel{0}{\pi}}$ & m户் \\
\hline & $\frac{9}{2}$ & 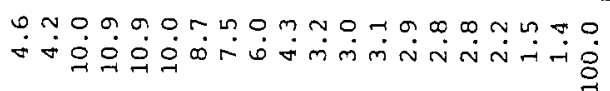 \\
\hline \multirow{3}{*}{$\begin{array}{l}0 \\
\infty \\
\stackrel{-}{-1} \\
\sim\end{array}$} & $\underset{\substack{\pi\\
}}{\stackrel{0}{0}}$ & 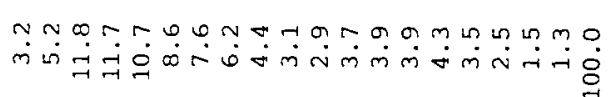 \\
\hline & 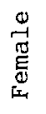 & 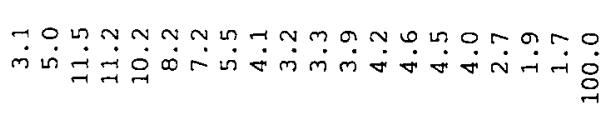 \\
\hline & $\frac{0}{2}$ & 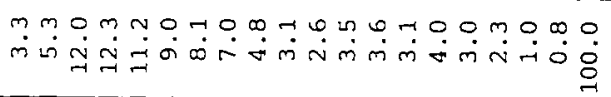 \\
\hline \multirow{3}{*}{ 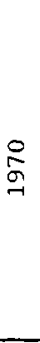 } & $\underset{\substack{\pi \\
\oplus}}{\stackrel{\pi}{0}}$ & 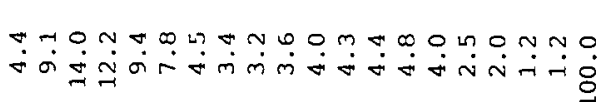 \\
\hline & 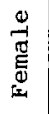 & 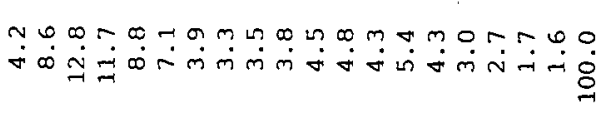 \\
\hline & $\underset{\stackrel{ \pm}{\pi}}{\stackrel{\pi}{2}}$ & 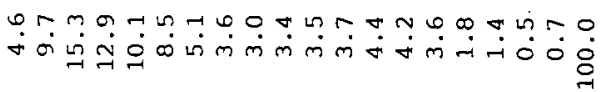 \\
\hline \multirow{4}{*}{$\begin{array}{l}\stackrel{0}{0} \\
\stackrel{0}{\sigma} \\
\text { r- }\end{array}$} & 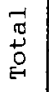 & 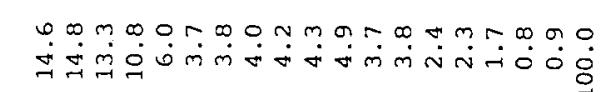 \\
\hline & 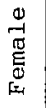 & 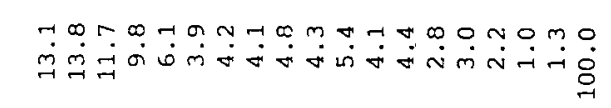 \\
\hline & $\underset{\frac{\pi}{2}}{2}$ & 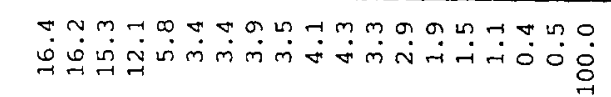 \\
\hline & 离 & 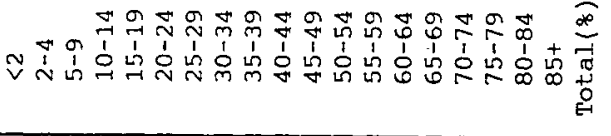 \\
\hline
\end{tabular}


MALE

FEMALE

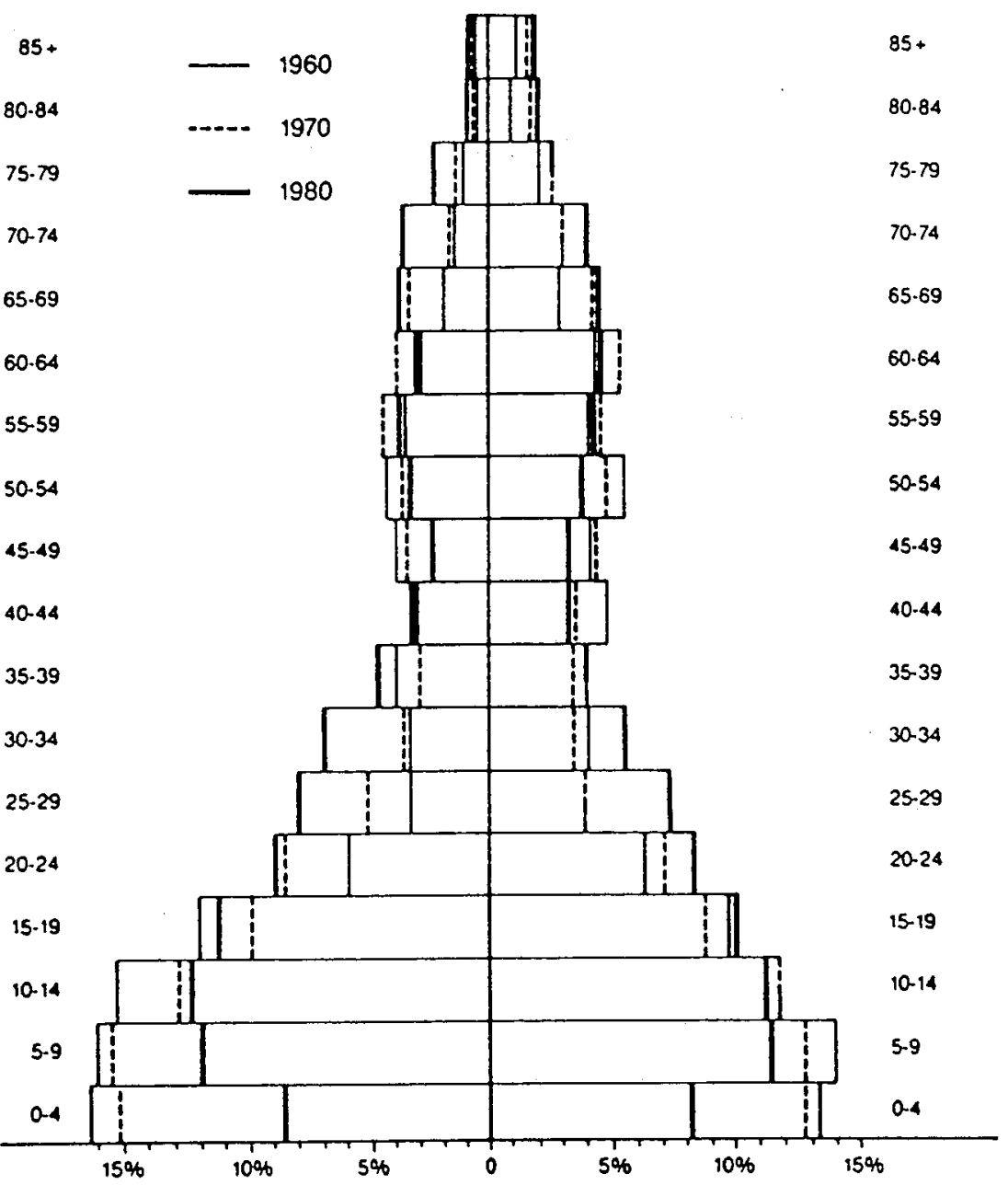

FIGURE 3. AGE - SEX PYRAMIDS FOR 1960, 1970, 1980

above Barbados - all countries that have had recent rapid fertility declines. However, Montserrat's population of 65 years and over in the early 1980s account for 12-13 per cent of the overall population and this percentage is well above those of Barbados and Argentina, double that of Chile and more than 
double those of Taiwan and Korea. In fact, Montserrat's percentage of 65 and over is more comparable to those of Hungary, France, the Netherlands and the United States, whose fertility levels have been at low levels for decades.

All of the foregoing points in the direction of the joint effect of recent and rapid decline from high fertility levels, significant net-migration loss and gains in population 65 years of age and over.

Sex composition. The primary determinants of sex structure are differentials in migration and mortaility since fertility adds a fairly constant ratio of males to females at the bottom of the age-sex pyramid. In Montserrat, like anywhere else, our expectation is that the effect of mortality on sex ratios is felt with increasing intensity as we move up to older ages. This subsection takes a brief look at the sex structure for the most recent three censuses. This is done by examining sex ratios, i.e., number of males per 100 females, as shown in Table 4 and Figure 4. The corresponding percentage distributions for each sex are shown in Table 3 and Figure 3.

For the total population, the number of males per 100 females for 1960 , 1970 , and 1980 increased from 80 to 88 and then to 93 . This is a reflection of the catching up of females with males in international migration. Indeed, whereas in the 1950s many more males than females were emigrating, a more sex-balanced emigration took place afterwards. Consequently, the sex ratios in Montserrat have moved towards less distortion. This is noticeable at nearly all age groups from 15 years and older. In general, among the resident population of Montserrat 15 and over, the numbers of males relative to females are higher in 1980 than in 1960. The sex ratios for 1970 are in general higher than those of 1960 and lower than those of 1980.

As should be expected, sex ratios decrease with advancing age. The effects of differential mortality and migration can be seen beginning with age 20 for the population of 1960 . This is carried through to the population age 30 and over in 1970 and 40 and over in 1980. This reflects the significant male selective net-migration loss mainly to the United Kingdom prior to 1960 . The higher number of males than females for the 20-29 age group in 1970 and the 25-39 age group in 1980 suggest that in recent years more young females than males have emigrated. The improvements in the sex ratios of the same cohorts across the 20 year period shown in Table 4 also suggests return migration, sex-differential immigration of retirees and/or improved mortality conditions for males. The first two are the most likely. 


\section{G. Edward Ebanks}

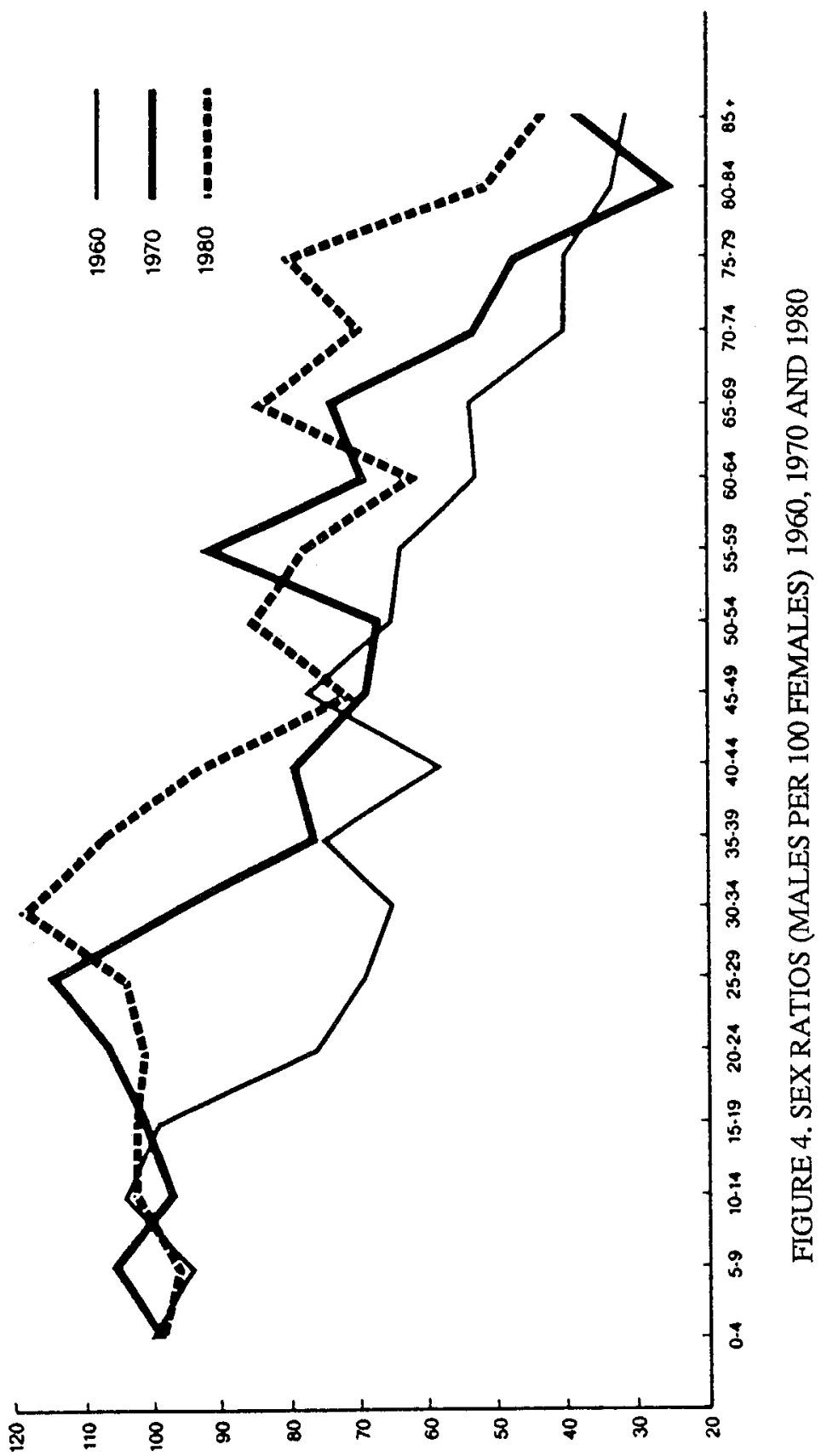


TABLE 4. SEX RATIOS 1960, 1970 AND 1980

$\begin{array}{lrcc} & \text { Sex Ratios } & \text { (males per } & 100 \text { females) } \\ \text { Age Group } & 1960 & 1970 & 1980 \\ 0-4 & & & \\ 5-9 & 100 & 99 & 98 \\ 10-14 & 94 & 105 & 96 \\ 15-19 & 104 & 97 & 102 \\ 20-24 & 99 & 101 & 102 \\ 25-29 & 76 & 106 & 101 \\ 30-34 & 69 & 114 & 104 \\ 35-39 & 65 & 96 & 118 \\ 40-44 & 75 & 76 & 107 \\ 45-49 & 58 & 79 & 92 \\ 50-54 & 77 & 69 & 72 \\ 55-59 & 65 & 67 & 85 \\ 60-64 & 64 & 91 & 78 \\ 65-69 & 53 & 69 & 62 \\ 70-74 & 54 & 74 & 84 \\ 75-79 & 40 & 53 & 70 \\ 80-84 & 40 & 47 & 80 \\ 85+ & 33 & 25 & 51 \\ \text { Total } & 31 & 38 & 43 \\ & 80 & 88 & 93\end{array}$

\section{Conclusions}

The relative stability in the size of the population of Montserrat has endured for close to 100 years. Various projections (Bouvier, 1985; Harewood, n.d.; United Nations Economic Commission for Latin America, 1987) have given expected population sizes of between 11 and 14 thousands for the year 2000 . My own guesstimate is that the population of Montserrat in the year 2000 will be around 12,500. Because of the size and level of productivity of the economy, it is important to have fairly realistic population projections in spite of the small size and small differences in the projections. However, the migration assumption is always shaky; yet it is perhaps the most crucial. 


\section{G. Edward Ebanks}

This relative stability in the size of the population over this considerable long time span has been achieved primarily through migration. Migration is nearly always a two-way stream process, with the streams generally being unbalanced. Montserrat has had both immigration and return migration but these have been superseded by emigration. Immigrants have come from the neighbouring islands and more recently in terms of retirees from Canada, the United Kingdom and the United States. Emigrants have gone to the neighbouring islands, the United States, Canada and the United Kingdom.

Net-migration loss has been substantial enough to slow population growth and has given rise to the relative stability in the size of the population. It has done this directly through removing young people and more males than females. Indirectly, the net-migration loss has contributed to a reduction in the number of births. Declining fertility has contributed towards the aging of the population and the aging population has been giving rise to an increase in the crude death rate.

The relatively low crude birth rate and high crude death rate resulting in low natural increase suggest that Montserrat has made substantial progress through the phases of the demographic transition. Montserrat would not have been this far along had it not been for migration and especially emigration.

Stability in population size for the last 95 years and anticipated stability in the future are unusual features for a society at a similar stage in its socioeconomic development. The unemployment rate is low because of emigration. The quality of life in Montserrat is relatively good. This is in no small part due to its relative stability in the size of the population for the last 95 years. This stability has facilitated economic planning and labour productivity is relatively high. Remittance from emigrants is an important economic input.

Montserrat is relatively well off, socially, economically and demographically; but this relative prosperity is not forever guaranteed. Controlled population growth and a dynamic economy based on all its resources (land, climate, sea and people) will provide the society with a fighting chance for survival in relative peace and prosperity. 


\section{References}

Bouvier, L.F. 1985. Montserrat: Yesterday, Today and Tomorrow. PRB Occasional Series. Washington, D.C.: The Caribbean Population Reference Bureau.

Caricom Secretariat. 1980-1981 Population Census of the Commonwealth Caribbean: Montserrat. Volumes 1, 2, 3. Georgetown, Guyana.

Caribbean Community Secretariat. 1984. Investor's guide to Montserrat. Georgetown, Guyana.

Charbit, Y. 1984. Caribbean Family Structure:Past Research and Recent Evidence from the WFS on Matrifocality. WFS Scientific Reports no. 65. Voorburg, Netherlands: International Statistical Institute.

Commonwealth Secretariat. 1983. Basic Statistical Data on Selected Countries. London, England.

Ebanks, G.E. 1985. Mortality, Fertility and Family Planning: Dominica and St. Lucia. Santiago, Chile: CIDA/CELADE.

1985. Infant and Child Mortality and Fertility: Trinidad-Tobago, Guyana, and Jamaica. WFS Scientific Reports no. 75. Voorburg, Netherlands: International Statistical Institute.

Government of Montserrat. Preliminary Data on Caribbean Population Census, Montserrat, Part I and II, 1980. Plymouth, Montserrat: Statistics Office. tics Office.

Statistical Digest 8 th (1979) and 9th (1984). Plymouth, Montserrat: Statis-

- Montserrat Vital Statistics Reports 1984, 1985 and various years (some results from 1986). Plymouth, Montserrat: Statistics Office. tics Office.

1984. National Account Statistics 1975-82. Plymouth, Montserrat: Statis-

1986. Health Report 1983, 1984. Plymouth, Montserrat: Ministry of Health.

Guengant J.P. 1985. Caribbean Population dynamics: Emigration and Fertility Challenges. Barbados: Letchworth Press Ltd.

Harewood, J. 1984. Mating and Fertility: Results from three WFS Surveys in Guyana, Jamaica, and Trinidad/Tobago. WFS Scientific Reports no. 67. Voorburg, Netherlands: International Statistical Institute.

n.d. Caribbean Demography Workbook Part A: Caribbean Demographic Situation. St. Augustine, Trinidad/Tobago: University of the West Indies, Institute for Social and Economic Research.

Jagdeo, T.P. 1985. IPPF/WHR Caribbean Contraceptive Prevalence Surveys, 2Montserrat. New York, New York: IPPF/WHR. 


\section{G. Edward Ebanks}

Lightbourne, R. and S. Singh. 1982. Fertility, union status and partners in the WFS Guyana and Jamaica Surveys, 1975-1976. Population Studies 36:201-25.

Population Reference Bureau. 1986. 1986 World Population Data Sheet. Washington, D.C.

United Nations, Economic Commission for Latin America and the Caribbean. 1982. Agricultural Statistics, Vols. IV and V. . Economic Survey 1984. Port of Spain, Trinidad/Tobago. 1987. Population Projections: Montserrat.

U.S. Department of Commerce, Bureau of the Census. 1979. A Complication of Age-Specific Fertility Rates for Developing Countries. International Research Document No. 7. Washington, D.C,

Received January, 1987; revised February, 1988 